\title{
ANALISIS TINGKAT PENDAPATAN PETANI GARAM KAWASAN PESISIR DI KABUPATEN REMBANG
}

\section{Yusiarica Aisyah Mirandi , Ida Nuraini , M. Sri Wahyudi Suliswanto}

Program Studi Ekonomi Pembangunan, Fakultas Ekonomi dan Bisnis, Universitas Muhammadiyah Malang, J1.Raya Tlogomas No.246 Malang, Indonesia

* Corresponding author: yusiaricaaisyah@gmail.com

\begin{tabular}{|c|c|}
\hline Artikel Info & Abstract \\
\hline Article history: & This study aims to analyze the effect of variable land area, \\
\hline Received 18 May 2019 & labor, working capital and selling prices on the income level of \\
\hline Revised 20 May 2019 & salt farmers in Rembang Regency. In this research using \\
\hline Accepted 11 June 2019 & primary data through the distribution of questionnaires and \\
\hline $\begin{array}{l}\text { Available online } 15 \text { June } \\
2019\end{array}$ & $\begin{array}{l}\text { direct interviews with } 45 \text { respondents of salt farmers as farmers } \\
\text { who are owners in Rembang Regency, with a list of questions } \\
\text { prepared. The analytical method used is multiple linear regrei, }\end{array}$ \\
\hline $\begin{array}{l}\text { Keyword: Income; land area; } \\
\text { labor; working capital and } \\
\text { selling price }\end{array}$ & $\begin{array}{l}\text { classic assumption test: normality, multicollinearity and } \\
\text { heteroscedacity, hypothesis testing : } T \text { statistical test, } F \\
\text { statistical test and coefficient of determination. The results of } \\
\text { this study indicate that the variable area of land, labor and }\end{array}$ \\
\hline JEL Classification & $\begin{array}{l}\text { selling prices have a significant positive effect on the income of } \\
\text { salt farmers, while for the working capital variable has a } \\
\text { positive but not significant effect on the income of salt farmers. }\end{array}$ \\
\hline
\end{tabular}

\section{PENDAHULUAN}

Garam merupakan komoditi strategi yang sangat penting potensial dan belum tergarap dengan baik. Masalah teknologi produksi, mutu garam yang dihasilkan, penyimpanan, pemasaran, dan pengaruh perubahan iklim merupakan sebagian masalah yang harus di perhatikan untuk terjaminnya persediaan garam. Perkembanagan usaha garam begitu dinamis, termasuk Kabupaten Rembang. Sebagai salah satu produsen garam penting di pesisir utara Jawa, Kabupaten Rembang memiliki posisi geografis strategis sebagai daerah potensial untuk produksi garam dengan kualitas tinggi. Garam juga merupakan produk unggulan daerah di Kabupaten Rembang bahkan garam tercantum dalam lambang daerah Kabupaten Rembang yaitu berupa gunungan garam berwarna putih (BPS, 2015). Pembuatan garam di Kabupaten Rembang sudah turun-temurun dilakukan dan sudah menjadi tradisi karena dilakukan secara turun-temurun dan pada waktu yang hampir sama yaitu pada musim kemarau. Pengembangan usaha garam yang tergolong padat karya, selain akan meningkatkan pendapatan petambak garam juga akan menimbulkan multiplier effect berupa membuka kesempatan dan lapangan kerja, mengurangi angka pengangguran dan penanggulangan kemiskinan di wilayah pesisir. Kondisi Kabupaten Rembang di wilayah pesisir sangat berpotensi untuk menghasilkan garam dengan kualitas tinggi, namun kondisi tersebut tidak didukung dengan peningkatan pendapatan tinggi yang dapat meningkatkan kesejahteraan petani garam di wilayah Kabupaten Rembang.

Penelitian ini didasari pada penelitian yang terdahulu yaitu penelitian yang berjudul "Pengembangan Faktor Produksi untuk Meningkatkan Pendapatan Petani Garam". (Komaryati, 2012), "Analisis Pendapatan dan Pemasaran Usaha Pembuatan Garam di Kelurahan Talise Kecamatan Mantikulore Kota Palu". (Ismail, 2015), "Efisiensi Faktor-Faktor Produksi 
Garam Rakyat". (Amami \& ihsannudin, 2016), Economic Potential of Salt Mining in Ghana Towards the Oil Find". (Affan \& Asamoah, 2011)

\section{METODE PENELITIAN}

Penelitian ini merupakan penelitian survey. Penelitian ini dilaksanakan di Kabupaten Rembang. Populasi dalam penelitian ini sejumlah 45 orang petani garam sebagai pemilik dan sampel sejumlah 45 orang petani garam sebagai pemilik. Data yang digunakan dalam penulisan ini adalah data primer. Metode pengumpulan data menggunakan observasi, kuisioner, dan wawancara. Teknik analisis data menggunakan regresi linier berganda yang digunakan untuk menentukan ada tidaknya pengaruh antara luas lahan, tenaga kerja, modal kerja dan harga jual terhadap pendapatan petani garam di Kabupaten Rembang.

\section{HASIL DAN PEMBAHASAN}

\section{Deskripsi Objek Penelitian}

Kabupaten Rembang yang bersemboyan: Rembang-BANGKIT adalah sebuah Kabupaten di Provinsi Jawa Tengah yang berbatasan dengan Teluk Rembang (Laut Jawa) di utara, Kabupaten Tuban (Jawa Timur) di timur, Kabupaten Blora di selatan, serta Kabupaten Pati di barat. Secara geografis terletak di ujung timur laut Provinsi Jawa Tengah dan dilalui Jalan Pantai Utara Jawa (Jalur Pantura), pada garis koordinat $111^{0} 00^{\prime}-111^{0} 30^{\prime}$ Bujur Timur dan $60^{\circ} 30^{\prime}$ - 70 6' Lintang Selatan.

Tabel 1. Profil Berdasarkan Struktur Umur Responden

\begin{tabular}{cccc}
\hline \multirow{2}{*}{ No } & Umur & Frekuensi & Responden \\
& & 0 & Presentase \\
\hline 1 & $21-30$ & 9 & $0 \%$ \\
2 & $31-40$ & 18 & $20 \%$ \\
3 & $41-50$ & 11 & $40 \%$ \\
4 & $51-60$ & 7 & $24 \%$ \\
5 & $\geq 61$ & $\mathbf{4 5}$ & $16 \%$ \\
\hline & Total & & $\mathbf{1 0 0} \%$ \\
\hline
\end{tabular}

Sumber : Data Primer, diolah 2019

Berdasarkan tabel 1 Profil rata-rata umur petani garam sebagai petani pemilik masih berusia produktif dapat dijelaskan pada klasifikasi umur 41-50 dengan persentase tertinggi sebesar $40 \%$ sebanyak 18 petani, sedangkan ratarata umur termuda pada klasifikasi umur 31-40 dengan persentase 20\% sebanyak 9 petani. Total keseluruhan petani pemilik di Kabupaten Rembang berjumlah 45 responden. 
Analisis Tingkat Pendapatan Petani Garam Kawasan Pesisir Di Kabupaten

Rembang

Mirandi

Nuraini

Suliswanto

Tabel 2. Profil Berdasarkan Struktur Status Perkawinan Responden

\begin{tabular}{cccc}
\hline \multirow{2}{*}{ No } & \multirow{2}{*}{ Status Kawin } & Frekuensi & Responden \\
& & 0 & Persentase \\
\hline 1 & Belum Kawin & 45 & $0 \%$ \\
2 & Kawin & 0 & $100 \%$ \\
3 & Cerai & $\mathbf{4 5}$ & $0 \%$ \\
\hline & Total & & $\mathbf{1 0 0 \%}$ \\
\hline
\end{tabular}

Sumber : Data Primer Diolah 2019

Profil status perkawinan petani garam sebagai petani pemilik dapat dilihat pada tabel 4.2 dapat dijelaskan dari total 45 responden bahwa petani pemilik di Kabupaten Rembang rata-rata sudah kawin dengan persentase $100 \%$.

Tabel 3. Profil Berdasarkan Beban Tanggungan Keluarga

\begin{tabular}{cccc}
\hline \multirow{2}{*}{ No } & \multirow{2}{*}{ Beban Tanggungan Keluarga (Anak) } & \multicolumn{2}{c}{ Responden } \\
& Tidak Memiliki & 4 & Prekentase \\
\hline 1 & 1 & 7 & $9 \%$ \\
2 & 2 & 20 & $16 \%$ \\
3 & $\geq 3$ & 14 & $44 \%$ \\
4 & Total & $\mathbf{4 5}$ & $\mathbf{1 0 0 \%}$ \\
\hline
\end{tabular}

Sumber: Data Primer Diolah 2019

Profil beban tanggungan keluarga (anak) petani garam sebagai petani pemilik di Kabupaten Rembang dapat dijelaskan pada tabel 4.3. Persentase tertinggi $44 \%$ dengan jumlah responden 20 orang yang memiliki anak 2 , dilanjut sebesar $31 \%$ dengan jumlah responden 14 orang yang memiliki anak kurang lebih 3 , dan $16 \%$ dengan jumlah responden 7 orang yang memiliki anak 1, sisanya sebesar $9 \%$ dengan responden 4 orang yang tidak memiliki anak.

Tabel 4. Profil Berdasarkan Tingkat Pendidikan

\begin{tabular}{cccc}
\hline \multirow{2}{*}{ No } & \multirow{2}{*}{ Tingkat Pendidikan } & \multicolumn{2}{c}{ Responden } \\
& Frekuensi & Presentase \\
\hline 1 & SD & 16 & $36 \%$ \\
2 & SMP & 20 & $44 \%$ \\
3 & SMU & 9 & $20 \%$ \\
4 & Sarjana & 0 & $0 \%$ \\
\hline & Total & $\mathbf{4 5}$ & $\mathbf{1 0 0 \%}$ \\
\hline
\end{tabular}

Sumber: Data Primer Diolah 2019

Profil tingkat pendidikan petani garam sebagai pemilik di Kabupaten Rembang pada tabel 4.4 dapat dijelaskan bahwa persentase tertinggi berada pada tingkat pendidikan SMP dengan persentase sebesar $44 \%$ dengan jumlah responden sebanyak 20 orang, selanjutnya tingkat SD dengan persentase $36 \%$ dengan jumlah responden sebanyak 16 orang, lalu pada tingkat SMU dengan persentase $20 \%$ dengan jumlah responden sebanyak 9 orang. Dari jumlah 
responden yang di ambil sebanyak 45 responden petani garam sebagai pemilik di Kabupaten Rembang.

\section{Tabel 5. Profil Berdasarkan Lama Usaha}

\begin{tabular}{cccc}
\hline No & Lama Usaha & Frekuensi & Responden \\
& & 9 & Presentase \\
\hline 1 & $0-10$ Tahun & 20 & $20 \%$ \\
2 & $11-20$ Tahun & 16 & $44 \%$ \\
3 & 21-30 Tahun & $\mathbf{4 5}$ & $36 \%$ \\
\hline & Total & $\mathbf{1 0 0 \%}$ \\
\hline
\end{tabular}

Sumber: Data Primer Diolah 2019

Profil rata-rata lama usaha pada tabel 4.5 dapat dijelaskan bahwa persentase tertinggi berada pada tingkat lama usaha kisaran 11-20 tahun dengan persentase $44 \%$ dengan jumlah responden sebanyak 20 orang, selanjutnya lama usaha kisaran 21-30 tahun dengan persentase 36\% dengan jumlah responden sebanyak 16 orang, lalu lama usaha kirasan 21-30 tahun dengan persentase 20\% dengan jumlah responden sebanyak 9 orang. Dari jumlah responden yang di ambil sebanyak 45 responden petani garam sebagai pemilik di Kabupaten Rembang.

Tabel 6. Distribusi Pendapatan Responden

\begin{tabular}{cccc}
\hline \multirow{2}{*}{ No } & \multirow{2}{*}{ Pendapatan } & \multicolumn{2}{c}{ Responden } \\
& & Frekuensi & Presentase \\
\hline 1 & $0-11.000 .000$ & 34 & $75 \%$ \\
2 & $11.000 .000-22.000 .000$ & 3 & $7 \%$ \\
3 & $22.000 .000-33.000 .000$ & 5 & $11 \%$ \\
4 & $33.000 .000-45.000 .000$ & 3 & $7 \%$ \\
\hline \multicolumn{2}{c}{ Total } & 45 & $100 \%$ \\
\hline
\end{tabular}

Sumber: Data Primer Diolah 2019

Distribusi rata-rata pendapatan responden pada tabel 4.6 dapat dijelaskan bahwa pendapatan tertinggi terdapat pada klasifikasi pendapatan (Rp. $0-\mathrm{Rp}$. 11.000 .000 ) pada persentase $74 \%$ dengan jumlah responden sebanyak 34 orang, sedangkan distribusi pendapatan terendah pada klasifikasi pendapatan (Rp. 11.000.000 - Rp. 22.000 .000 ) pada persentase 7\% dengan jumlah responden sebanyak 3 orang dan (Rp. 33.000.000 - Rp. 45.000.000) pada persentase 7\% dengan responden sebanyak 3 orang. Berdasarkan hasil data penelitian dapat diketahui bahwa tingkat pendapatan tertinggi yaitu sebesar Rp. 45.000.000,", sedangkan pendapatan terendah yaitu sebesar Rp. 1.500.000,", dengan ratarata pendapatan sebesar Rp 9.800.000,, . 
Tabel 7. Distribusi Tenaga Kerja Responden

\begin{tabular}{cccc}
\hline \multirow{2}{*}{ No } & Tenaga Kerja & \multicolumn{2}{c}{ Responden } \\
& & Frekuensi & Presentase \\
\hline 1 & $1-2$ & 31 & $69 \%$ \\
2 & $3-5$ & 10 & $22 \%$ \\
3 & $5-7$ & 2 & $5 \%$ \\
4 & $8-10$ & 2 & $4 \%$ \\
\hline & Total & 45 & $100 \%$ \\
\hline
\end{tabular}

Sumber: Data Primer Diolah 2019

Distribusi tenaga kerja responden pada tabel 4.7 dapat dijelaskan bahwa persentase tertinggi terdapat pada jumlah tenaga kerja sejumlah 1-2 dengan frekuensi sebanyak 32 orang dan nilai 69\%. Sedangkan persentase terendah terdapat pada jumlah tenaga kerja sejumlah 8-10 dengan frekuensi sebanyak 2 orang dan nilai $4 \%$.

\section{Tabel 8. Distribusi Modal Usaha Responden}

\begin{tabular}{|c|c|c|c|}
\hline \multirow{2}{*}{ No } & \multirow{2}{*}{ Modal } & \multicolumn{2}{|c|}{ Responden } \\
\cline { 2 - 4 } & & Frekuensi & Presentase \\
\hline 1 & $0-500.000$ & 12 & $27 \%$ \\
\hline 2 & $500.000-1.000 .000$ & 21 & $46 \%$ \\
\hline 3 & $1.000 .000-1.500 .000$ & 8 & $18 \%$ \\
\hline 4 & $1.500 .000-2.000 .000$ & 4 & $9 \%$ \\
\hline & Total & $\mathbf{4 5}$ & $\mathbf{1 0 0 \%}$ \\
\hline
\end{tabular}

Sumber: Data Primer Diolah 2019

Distribusi rata-rata modal usaha responden pada tabel 4.8 dapat dijelaskan tingkat tertinggi terdapat pada klasifikasi modal sebesar (Rp. $500.000-\mathrm{Rp}$. 1.000.000) dengan frekuensi 21 dan persentase sebesar 46\%. Dan tingkat terendah terdapat pada klasifikasi modal sebesar (Rp 1.500.000- Rp. 2.000.000) dengan frekuensi 4 dan persentase sebesar 9\%.

Tabel 9. Distribusi Harga Jual Responden

\begin{tabular}{|c|c|c|c|}
\hline \multirow{2}{*}{ No } & \multirow{2}{*}{ Harga Jual } & \multicolumn{2}{|c|}{ Responden } \\
\cline { 3 - 4 } & & Frekuensi & Presentase \\
\hline 1 & $0-250$ & 0 & $0 \%$ \\
\hline 2 & $250-500$ & 0 & $0 \%$ \\
\hline 3 & $500-750$ & 25 & $56 \%$ \\
\hline 4 & $750-1000$ & 20 & $44 \%$ \\
\hline & Total & $\mathbf{4 5}$ & $\mathbf{1 0 0} \%$ \\
\hline
\end{tabular}

Sumber: Data Primer Diolah 2019

Distribusi rata-rata harga jual responden dapat dijelaskan pada gambar 4.9, bahwa persentase tertinggi sebesar 56\% dengan harga jual (Rp. 500- Rp. 750) dan frekuensi sebanyak 25 orang, sedangkan untuk persentase terendah 
sebesar 44\% dengan harga jual (Rp. 750 - Rp. 1000) dan frekuensu sebanyak 20 orang.

\section{Tabel 10. Distribusi Luas Lahan Responden}

\begin{tabular}{|c|c|c|c|}
\hline \multirow{2}{*}{ No } & \multirow{2}{*}{ Luas Lahan } & \multicolumn{2}{|c|}{ Responden } \\
\cline { 3 - 4 } & & Frekuensi & Presentase \\
\hline 1 & $0.5-1 \mathrm{Ha}$ & 10 & $22 \%$ \\
\hline 2 & $1-1.5 \mathrm{Ha}$ & 13 & $29 \%$ \\
\hline 3 & $2-2.5 \mathrm{Ha}$ & 14 & $31 \%$ \\
\hline 4 & $2.5-3 \mathrm{Ha}$ & 1 & $2 \%$ \\
\hline 5 & $3-3.5 \mathrm{Ha}$ & 4 & $9 \%$ \\
\hline 6 & $3.5-4 \mathrm{Ha}$ & 2 & $5 \%$ \\
\hline 7 & $4-4.5 \mathrm{Ha}$ & 1 & $\mathbf{1 0 0} \%$ \\
\hline & Total & $\mathbf{4 5}$ & \\
\hline
\end{tabular}

Sumber: Data Primer Diolah 2019

Distribusi rata-rata luas lahan responden dapat dijelaskan pada gambar 4.11, bahwa persentase tertinggi sebesar 31\% dengan luas lahan 2-2.5 Ha dan frekuensi sebanyak 14 orang, selanjutnya persentase $29 \%$ dengan luas lahan 1$1.5 \mathrm{Ha}$ dan frekuensi sebanyak 13 orang, sedangkan untuk persentase terendah sebesar 2\% dengan luas lahan 2.5-3 Ha dan 4-4.5 Ha dengan frekuensi sebanyak 1 orang.

\section{Uji Asumsi Klasik}

1. Uji Normalitas

\section{Tabel 11. Uji Normalitas}

\begin{tabular}{|c|c|c|}
\hline Smapel & Jarque-Bera & Signifikansi \\
\hline 45 & 1.258358 & 0.533029 \\
\hline
\end{tabular}

Sumber: Data Primer diolah 2019

Uji normalitas bertujuan untuk mengkaji apakah model regresi dalam variabel bebas dan variabel terikat keduanya berdistribusi secara normal atau tidak. Normalitas data penelitian dilihat dengan cara diperoleh pvalue statistik uji Jarque-Bera sebesar 0.5330, dimana nilai tersebut lebih besar dari 0,05 sehingga diputuskan untuk gagal tolak H0. Hal ini dapat disimpulkan bahwa asumsi normalitas error/residual terpenuhi.

2. Uji Multikolinearitas

Tabel 12. Uji Multikolinieritas

\begin{tabular}{|c|c|}
\hline Variabel & Nilai Centered VIF \\
\hline Luas Lahan & 1.000016 \\
\hline Tenaga Kerja & 0.792443 \\
\hline Modal Kerja & 0.786419 \\
\hline Harga Jual & 0.643779 \\
\hline
\end{tabular}

Sumber: Data Primer diolah 2019 
Multikolinieritas adalah adanya korelasi yang linier antara variabelvaraibel bebas dalam model regresi. Kolinieritas terjadi jika diantara varaibel bebas terjadi korelasi satu dengan yang lainnya atau berkorelasi tetapi tidak lebih tinggi $\mathrm{R}^{\wedge} 2$, maka dikatakan tidak terjadi multikolieritas. Uji multikolinieritas dalam penelitian dilihat nilai kolerasi antara varaibel independen kurang dari 0.8 dinyatakan aman maka data tersebut dinyatakan tidak terjadi multikolinieritas.

3. Uji Heteroskedasitas

Tabel 13. Uji Heteroskedastisitas

\begin{tabular}{|c|c|}
\hline Variabel & Signifikansi \\
\hline $\mathrm{X} 1$ & 0.9565 \\
\hline $\mathrm{X} 2$ & 0.2598 \\
\hline $\mathrm{X} 3$ & 0.9951 \\
\hline $\mathrm{X} 4$ & 0.7000 \\
\hline
\end{tabular}

Sumber: Data Primer diolah 2019

Uji ini digunakan untuk melihat apakah dalam model regresi terjadi ketidaksamaan variance dari residual satu ke pengamatan yang lain. Uji heteroskedastisitas menggunakan uji glejser pada data penelitian dijelaskan bahwa nilai prob tidak ada yang signifikan yaitu lebih dari 5\%, maknanya tidak ada satupun variabel independen yang mempengaruhi variabel ARESID jadi tidak terjadi heteroskedastisitas.

\section{Analsis Regresi Berganda}

Hasil estimasi yang dilakukan di atas dapat dijelaskan bahwa koefisisen determinasi $\left(\mathrm{R}^{\wedge} 2\right)$ pada penelitian adalah sebesar 0.900091 yang berarti $90.0 \%$ pendapatan petani garam sebagai pemilik dapat dijelaskan ielh seluruh variabel bebas dalam penelitian ini. Selanjutnya, dari hasil estimasi uji $\mathrm{T}$ dapat diketahui terdapat tiga variabel yang berpengaruh nyata terhadap pendapatan petani garam. Variabel tersebut adalah luas lahan, tenaga kerja dan harga jual. Sedangkan variabel lainnya yaitu modal kerja tidak berpengaruh nyata terhadap pendapatan tetapi berhubungan positif terhadap pendapatan petani garam. Dari hasil estimasi uji $\mathrm{F}$ dapat diketahui bahwa varaibel bebas luas lahan, tenaga kerja, modal kerja dan harga jual mempunyai pengaruh terhadap variabel dependen yaitu pendapatan petani garam di Kabupaten Rembang. Hasil analisis dapat dijelaskan sebagai berikut :

1. Pengaruh Luas Lahan terhadap Pendapatan

Pada uji signifikan t-test secara individual maupun f-test secara serentak menunjukkan bahwa variabel luas lahan (X1) berpengaruh signifikan terhadap pendapatan petani garam di Kabupaten Rembang. Berdasarkan uji t-test dengan probabilitas luas lahan (X1) $0.0000<\alpha 0.05$ dengan koefisien regresi sebesar 8808385. Secara statistik menunjukkan bahwa apabila luas lahan naik 1\% maka akan menurunkan pendapatan petani garam sebesar 8808385 persen.

Keadaan di atas menunjukkan keberadaan luas lahan sangat berpengaruh dalam produksi garam, penggunaan yang intensif akan 
menentukan seberapa besar tingkat produksi yang dihasilkan. Hasil tersebut sesuai dengan penelitian yang dilakukan oleh Saihani (2011) dimana menunjukkan bahwa terdapat pengaruh luas lahan terhadap pendapatan yang diperoleh petani. Luas lahan yang semakin berkurang akan berakibat pada turunnya hasil produksi. Penelitian ini sejalan dengan penelitian yang dilakukan IIS Wahyu Nur Hidayat, (2007). Dengan judul Analisis Pengaruh Luas lahan, jumlah Produksi dan Biaya Produksi Terhadap Pendapatan Petani Padi di Kecamatan Delangga Kabupaten Klaten (Studi kasus di Desa Sribit) yang menyatakan bahwa varaibel luas lahan berpengaruh positif dan signifikan terhadap ppendapatan petani artinya besar kecilnya luas lahan berpengaruh terhadap tinggi rendahnya pendapatan petani. Pendapat lain juga dikemukakan pada hasil penelitian yang dikemukakan oleh Rusdiah Nasution (2015) yang menyatakan bahwa luas lahan berpengaruh nyata terhadap pendapatan petani bawang merah. Adisarwanto (2002:45), berpendapat bahwa penggunaan lahan yang baik secara permanen ataupun siklus terhadap suatu kumpulan sumberdaya alam dan sumberdaya buatan yang secara keseluruhannya disebut lahan dengan tujuan untuk mencukupi kebutuhan baik berupa kebendaan maupun spiritual maupun kedua-duanya.

Oleh karena itu penambahan luas lahan perlu ditambahkan agar hasil dari produksi garam pun semakin meningkat dan menambah pendapatan petani garam sebagai pemilik. Akan tetapi hal tersebut mungkin sulit dilakukan karena pada kenyataannya di lapangan bahwa penambahan luas lahan tersebut tidaklah mudah dikarenakan lahan merupakan faktor yang sangat terbatas jumlahnya apalagi dengan banyaknya lahan sawah yang sekarang dijadikan sebagai perumahan.

2. Pengaruh Tenaga Kerja terhadap Pendapatan

Pada uji signifikan t-test secara individual maupun f-test secara serentak menunjukkan bahwa variabel tenaga kerja (X2) berpengaruh signifikan terhadap pendapatan petani garam di Kabupaten Rembang. Berdasarkan uji t-test dengan probabilitas tenaga kerja (X2) $0.0314>\alpha 0.05$ dengan koefisien regresi positif sebesar 1706875. Dengan demikian dapat diartikan bahwa semakin banyak tenaga kerja maka akan semakin banyak pula tingkat pendapatan petani garam yang di terima.

Tenaga kerja merupakan orang-orang yang telah dapat memenuhi syarat-syarat yang ditetapkan dalam undang-undang perburuan di negara yang bersangkutan (Hasibunan, 2009). Besarnya penyediaan tenaga kerja dalam masyarakat adalah jumlah orang yang menawarkan jasa untuk produksi. Di antaranya sebagian sudah aktif dalam kegiatan menghasilkan barang atau jasa, golongan ini disebut golongan yang bekerja (employed person). Golongan yang siap bekerja dan sedang berusaha mencari pekerjaan disebut pencari kerja atau pengangguran. Tenaga kerja merupakan salah satu faktor produksi yang utama dalam perusahaan, sebagai pelaku proses produksi samapi dihasilkan barang maupun jasa. Hasil analisis tersebut sejalan dengan pemikiran Daniel (2002) mengatakan, pengaruh tenaga kerja terhadap produksi tidak sama pada setiap cabang produksi. 
Peryataan tersebut sependapat dengan Kardiman (2003) yang menyatakan tenaga kerja adalah segala kegiatan jasmani atau rohani atau pikiran manusia yang ditujukan untuk kegiatan produksi. Hasil penelitian ini didukung oleh penelitian sebelumnya yang dilakukan oleh Heni Rahayu (2015) yang menyimpulkan bahwa variabel tenaga kerja berpengaruh positif dan signifikan terhadap pendapatan suatu usaha.

3. Pengaruh Modal Kerja terhadap Pendapatan

Pada uji signifikan t-test secara individual maupun f-test secara serentak menunjukkan bahwa variabel modal kerja (X3) berpengaruh signifikan terhadap pendapatan petani garam di Kabupaten Rembang. Berdasarkan uji t-test dengan probabilitas modal kerja (X3) $0.0897<\alpha 0.05$ dengan koefisien regresi positif sebesar 3,725140. secara statistik menunjukkan bahwa apabila modal kerja naik $1 \%$ maka akan meningkatkan pendapatan petani garam sebesar 3,725140 persen. Berdasarkan hasil regresi menyatakan bahwa faktor modal kerja tidak berpengaruh nyata terhadap pendapatan petani garam, semakin besar modal kerja yang dikeluarkan oleh petani garam maka pendapatan yang akan diterima semakin menurun. Modal kerja merupakan keseluruahn biaya yang digunakan oleh petani garam untuk menghasilkan output dalam satukali panen. Berdasarkan hasil analisis di atas, variabel modal berpengaruh langsung dan signifikan terhadap pendapatan, apabila modal ditingkatkan maka produksi juga akan meningkat, dengan meningkatnya produksi pendapatan akan meningkat (Albertus, 2016).

Semakin besar modal usaha yang digunakan akan diikuti dengan meningkatnya pendapatan usaha, asumsinya bahwa dengan modal yang besar maka usaha yang dimiliki akan memungkinkan bertambahnya jenis produksinya, sehingga akan menarik minat pembeli dan mampu menambah pendapatan suatu usaha (Ardiansyah, 2010). Peningkatan dalam modal kerja yang digunakan dapat mempengaruhi pendapatan petani garam, karena modal kerja yang digunakan dapat mempengaruhi jumlah produksi yang dihasilkan sehingga akan meingkatkan pendapatan petani garam. Hasil penelitian ini mendukung penelitian Listyawan Adi Nugraha (2011:9) dimana penelitian tersebut menyatakan bahwa modal usaha berpengaruh positif terhadap tingkat pendapatan yang dimana modal bukanlah segala-galanya dalam sebuah bisnis.

4. Pengaruh Harga Jual terhadap Pendapatan

Pada uji signifikan t-test secara individual maupun f-test secara serentak menunjukkan bahwa variabel harga jual (X4) berpengaruh signifikan terhadap pendapatan petani garam di Kabupaten Rembang. Berdasarkan uji t-test dengan probabilitas produksi (X3) $0.0317<\alpha 0.05$ dengan koefisien regresi positif sebesar 4951658. Penelitian ini sejalan dengan pernyataan Fandy Tjiptono (2005:151) yang menyatakan bahwa harga jual merupakan satuan moneter atau ukuran lainnya termasuk barang maupu jasa yang diukur agar memperoleh hak kepemilikan atau penggunaan suatu barang atau jasa yang akan berpengaruh langsung terhadap laba perusahaan. Menurut (Mulyadi 2005) ."pada prinsipnya harga jual harus dapat menutupi biaya penuh ditambah dengan laba yang 
wajar. Harga jual sama dengan biaya produksi ditamabh mark-up". Penetapan harga jual yang tepat merupakan salah satu faktor terpenting salam suatu usaha kurang berarti jika sebuah perusahaan dapat memproduksi barang dengan sangat baik namun tidak menetapkan harga jual yang tepat untuk barang produksinya. Menurut pendapat Case \& Faair (2006:49) harga jual akan menentukan dan mengukur seberapa pendapatan yang akan diterima. Hal ini menandakan bahwa semakin tinggi tingkat harga, maka akan semakin bagus pengaruhnya terhadap pendapatan bersih yang diterima petani. Penelitian yang dilakukan Rasyid, Kasim, \& Kurniawan (2012) dan Crisdandi (2015) menyatakan bahwa harga jual berpengaruh positif terhadap pendapatan. Dikarenakan jika harga jual suatu produk naik maka pendapatan perusahaan juga akan naik.

Hasil wawancara yang diperoleh peneliti dikalangan petani garam, bahwasanya harga jual yang petani sering alami terkadang rendah dan terkadang melambung tinggi artinya harga jual tidak memiliki ketetapan. Terkadang ketika hasil panen yang diperoleh petani garam banyak namun harga jual rendah yang mengakibatkan pendapatan petani garam tidak meningkat.

\section{KESIMPULAN DAN SARAN}

Hasil perhitungan statistik menunjukkan bahwa koefisien variabel luas lahan berpengaruh positif dan signifikan terhadap pendapatan dengan nilai sebesar 8808385. sehingga dapat disimpulkan bahwa semakin luas lahan akan semakin tinggi pendapatan yang dihasilkan. Variabel tenaga kerja berpengaruh positif dan signifikan terhadap pendapatan, yaitu nilai koefisien sebesar 1706875 sehingga dapat disimpulkan bahwa semakin banyak tenaga kerja yang dimiliki akan menghasilkan pendapatan yang tinggi.. Pengaruh modal terhadap pendapatan mempunyai nilai koefisien 3.725140 dan berpengaruh positif tetapi tidak signifikan, sehingga dapat disimpulkan bahwa semakin banyak modal kerja yang dikeluarkan oleh petani garam maka akan meningkatkan produksi dan pendapatan. Pengaruh variabel harga jual berpengaruh positif dan signifikan terhadap pendapatan dengan nilai sebesar 4951658 sehingga dapat disimpulkan bahwa semakin tinggi harga jual garam akan semakin meningkatkan pendapatan.

Penelitian ini hanya berfokus pada empat variabel yaitu luas lahan, tenaga kerja, modal dan harga jual. Dalam pembahasan dalam pembahasan modal kerja berpengaruh positif tetapi tidak signifikan secara nyata, untuk penelitian selanjutnya agar menambah dan melakukan penambahan populasi dan variabel agar lebih terlihat apa saja yang mampu mempengaruhi tingkat pendapatan petani garam. Disarankan untuk para petani garam khususnya petani pemilik agar melakukan usaha garam dengan biaya seefisien mungkin sehingga dari pengalokasian biaya yang tepat dan efisien dapat diperoleh hasil yang maksimal.

\section{DAFTAR PUSTAKA}

Abdullah, Z. A., \& Susandini, A. (2018). MEDIA PRODUKSI(GEOMEMBRANE)DAPAT MENINGKATKAN KUALITAS 
HARGA JUAL GARAM(STUDY KASUS: LADANG GARAM MILIK RAKYAT DI WILAYAH MADURA). Ecp-Entrepreneurship, Vol 3 No 2 Juni 2018, 21-36.

Adiwilaga, P. I. (1982). Ilmu Usaha Tani. Bandung: Offset Alumni Bandung.

Affan, M., \& D.N. Asamoah. (2011). Ecominic Potential of Salt Mining in Ghana Towards the Oil Find. Research Journal of Environmental and Earth Sciences, 448-456.

BPS, K. R. (2015, Januari 1). KABUPATEN REMBANG BPS. Retrieved April 5, 2019, from KABUPATEN REMBANG BPS: https://rembangkab.bps.go.id

C.E Bishop., \& W.D. Toussaint. (1979). Pengantar Analisa Ekonomi Pertanian. Jakarta: Mutiara Jakarta. PRES.

Harold , G., \& Armand , S. (1994). Ekonomi Pertanian. Malang: UMM

Herman, S., Eriyatno, Noor, E., \& Mulyadi, D. (2014). Identifikasi Faktor Kunci Krisis Pada Tataniaga Garam Konsumsi Di Indonesia Menggunakan Proses Jejaring Analitik (Analytic Network Process). Jurnal Riset Industri (Journal of Industrial Research), Vol.8 No.3, Desember 2014, Hal. 205-214, 205-214.

Hidayat, Y. A. (2016). Produksi Garam Kristal dan Perilaku Mengantisipasi Penurunan Harga. ISSN 2089-3590,EISSN 2303-2472 Vol6, No.1, Th,2016, 2089-3590,2303-2472.

Izzaty, \& Pratama, S. H. (2011). Kebijakan Pengembangan Produksi Garam Nasional. Jurnal Ekonomi \& Kebijakan Publik, Vol.2, Nomor 2, Desember 2011, 657-680.

Khakim, L., W.Pratomo, A., \& M. Nahar. (2014). Adopsi Internet Marketing Pada UKM Pengolah Garam Rembang. SEMANTIK 2014, ISBN: 979-26-0276-3 15 November 2014, 160-163.

Kurniawan, T., \& Azizi, A. (2013). Dampak Kebijakan Impor Dan Kelembagaan Tewrhadap Industri Garam Internasioanal. J. Kebijakan Sosek KP Vol.3 No.1 Tahun 2013, 1-13.

Masri , S., \& Sofian, E. (1987). Metode Penelitian Survai. Yogyakarta: PT Pustaka LP3ES Indonesia .

Maulina, C. N., Husaini, \& Nurasiah. (2017). Kehidupan Petani Garam Di Gampong Lancang Paru Kecamatan Bandar Baru Kabupaten Pidie Jaya Thaun 1940-2015. Jurnal Ilmiah Mahasiswa (JIM) Program Studi Pendidikan Sejarah Vol.2, No.1, Januari 2017, hlm.20-33, 20-33.

Mubyarto. (1972). Pengantar Ekonomi Pertanian. Yogyakarta: PT Pustaka LP3ES Indonesia .

Mun'im, A. (2015). Analisis Usaha Petambak Garam Dan Perannya Dalam Perekonomian Tahun 2012 (Studi Kasus Petambak Garam PUGAR). J. Sosek KP Vol.10 No.2 Tahun 2015: 217-228, 217-228. 
P.Andriyani, R., Suadi, \& S.Djasmani, S. (2013). ANALISIS USAHA TAMBAK GARAM DI DESA GEDUNGMULYO KECAMATAN LASEM KABUPATEN REMBANG. Jurnal Perikanan (J. Fish. Sci.) XV (2): 68-77 ISSN: 0853-6384, 68-77.

Rikah, \& Kusumaningsih, N. (2018). Faktor Yang Mempengaruhi Tingkat Pendapatan Petani Garam Kawasan Pesisir Kabupaten Rembang. Fokus Ekonomi Vol. 13 No. 2 Desember 2018 : 316-330, 316-330.

Rochwulaningsih, Y. (2013). Tata Niaga Garam Rakyat Dalam Kajian Struktural . Jurnal Sejarah CITRA LEKNA, Vol. XVII, No. 1 Februari 2013: 59-66, 59-66.

Sukirno, S. (1982). Pengantar Teori Mikroekonomi. Jakarta: Fakultas Ekonomi Universitas Indonesia.

Sukirno, S. (1994). Pengantar Teori Mikroekonomi . Jakarta: PT RajaGrafindo Persada.

Wahid, A. (2015). Politik Ekonomi Garam Di Indonesia Pada Masa Kolonial 1850-1940. Jejak Nusantara Volume 03 Agustus 2015, 101-117.

Wijaya, R. A., Rahardian, R., \& Apriliani, T. (2014). Analisis Peran Kelembagaan Penyedia Input Prodiuksi Dan Tenaga Kerja Dalam Usaha Tambak Garam. J.Sosek KP Vol.9 No. 1 Tahun 2014, 29-40.

Winarsih, Boedhowi, \& Bandi. (2014). Pengaruh Tenaga Kerja, Teknologi, Dan Modal Dalam Meningkatkan Produksi Di Industri Pengelolaan Garam Kabupaten Pati. Jurnal Pendidikan Insan Mandiri : Vol.3 No.2 (2014), 88-98.

Yanti, B. V., Apriliani, T., \& Kurniawan, T. (2017). Peningkatakan Pengetahuan Petambak Garam Berkaitan Dengan Pemanfaatan Air Limbah Tambak Garam Untuk Peningkatan Kesejahteraan Petambak Garam. Journal for Business and Entrepreneur ISSN 2501-6682 Vol.1 No.1 July-December 2017, 2501-6682.

Zakki, N., \& Sayyida. (2016). Faktor-Faktor Ynag Mempengaruhi Pendapatan Dan Kesejahteraan Petani Garam Rakyat Kawasan Pesisir Kalianget . Jurnal "PERFORMANCE" Bisnis \& Akuntansi Volume VI, No.1, Maret 2016, 66-85. 